\title{
Zmiana struktury przestrzennej działalności badawczo- -rozwojowej europejskich przedsiębiorstw produkcyjnych w warunkach kryzysu gospodarczego
}

\author{
Changes in the spatial structure of the research \\ and development activity in European manufacturing \\ enterprises under economic crisis conditions
}

\begin{abstract}
Streszczenie: Jedną z ważnych konsekwencji kryzysu gospodarczego dla europejskich przedsiębiorstw produkcyjnych jest pojawienie się zjawiska tzw. relokalizacji działalności produkcyjnej i związana z nią bezpośrednio zmiana struktury przestrzennej działalności badawczo-rozwojowej (B+R). Zmiana struktury przestrzennej w aspekcie działalności $\mathrm{B}+\mathrm{R}$ uwarunkowana jest wieloma czynnikami, spośród których najważniejsze są: czynniki ekonomiczne (w tym ulgi i dotacje na działalność $B+R$, aspekty kosztowe), czynniki technologiczne (ze szczególnym uwzględnieniem bliskości jednostek naukowych i centrów transferu technologii), czynniki kulturowe (w tym związane z koncepcją społecznej odpowiedzialności biznesu w przedsiębiorstwach), czynniki społeczne i demograficzne (powiązane z potencjałem demograficznym poszczególnych lokalizacji), czynniki administracyjno-prawne (w tym otoczenie instytucjonalne). Celem pracy jest identyfikacja i analiza podstawowych kierunków i uwarunkowań zmiany struktury przestrzennej działalności B+R w europejskich (w tym polskich) przedsiębiorstwach, (szczególnie) działających w branży motoryzacyjnej i lotniczej (grupa branż high-tech).
\end{abstract}

\begin{abstract}
One of the important consequences the economic crisis had on European production is the phenomenon of relocation of production and the directly associated change in the spatial structure of research and development (R\&D). Changes in the spatial structure in terms of R\&D activity are conditioned by many factors, among which the most important are: economic factors (including incentives and grants for R\&D, cost aspects); technological factors (with particular regard to the proximity of research units and centers of technology transfer); cultural factors (including those associated with the concept of Corporate Social Responsibility in companies); social and demographic factors (related to the demographic potential of each location); administrative and legal factors. The aim of the paper is the identification and analysis of basic trends and determinants of changes in the spatial structure of R\&D in the European businesses, (especially) operating in the automotive and aviation (high-tech group) industries.
\end{abstract}

Słowa kluczowe: badania i rozwój; innowacje; struktura przestrzenna

Keywords: research and development; innovation; spatial structure 


\section{WSTĘP}

Działalność badawczo-rozwojowa $(\mathrm{B}+\mathrm{R})$ stanowi jeden z podstawowych czynników rozwoju gospodarczego przedsiębiorstw, a co za tym idzie, ma bezpośredni wpływ na klasyfikację danych krajów w rankingach innowacyjności opracowywanych przez różne organizacje międzynarodowe, np. Unię Europejską (Innovation Union Scoreboard) czy UNCTAD ${ }^{1}$ (Globalization of $R \& D$ and Developing Countries). W tym kontekście zauważalne jest, iż jedną z ważnych konsekwencji kryzysu gospodarczego dla europejskich przedsiębiorstw produkcyjnych jest intensyfikacja zjawiska tzw. relokalizacji działalności produkcyjnej i związana z nią bezpośrednio zmiana struktury przestrzennej działalności badawczo-rozwojowej w zróżnicowanych konfiguracjach, uwarunkowanych ekonomicznie, technologicznie, demograficznie, a nawet kulturowo. Celem pracy jest identyfikacja i analiza podstawowych kierunków i uwarunkowań zmiany struktury przestrzennej działalności B+R w europejskich (w tym polskich) przedsiębiorstwach przemysłowych.

\section{ZAŁOŻENIA METODOLOGICZNE PRACY}

Przedstawione w pracy wnioski na temat zachowania europejskich przedsiębiorstw w zakresie zmiany (ze szczególnym uwzględnieniem jej kierunków) struktury przestrzennej działalności badawczo-rozwojowej oparto na analizach dokumentów źródłowych i własnych obserwacjach autora, z wykorzystaniem przedstawionych poniżej źródeł.

- Wyniki badań przeprowadzonych przez firmę konsultingową Arthur D. Little w latach 2006-2008, którymi to badaniami objęto branżę samochodową, lotniczą i zbrojeniową - łącznie ponad 280 przedsiębiorstw. Badania objęły poszerzony wywiad ankietowy z największymi przedsiębiorstwami wskazanych branż (55\% ankiet dla branży samochodowej, $30 \%$ ankiet dla branży lotniczej i 15\% ankiet dla branży zbrojeniowej). W ankietach badano m.in. główne kierunki oraz powody delokalizacji z uwzględnieniem poszczególnych badanych branż. Finalnym podsumowaniem badań było opracowanie macierzy wskaźników kosztowych i jakościowych procesu delokalizacji działalności B+R. Badania te wskazują również w wyraźny sposób bardzo duży wpływ Chin i Indii jako krajów, do których najczęściej przenoszona jest działalność $\mathrm{B}+\mathrm{R} \mathrm{w}$ analizowanych branżach (Delocalization of $R \& D$ - Development to follow the production trend?, 2006).

- Wyniki badań realizowanych w ramach projektu Industrial Research Monitoring and Analysis IRMA, które przeprowadzono w 2008 roku, a badaniami objęto 130 największych europejskich przedsiębiorstw. Projekt, współfinansowany ze środków Komisji Europejskiej, realizowany był w trzech fazach. W pierwszych dwóch analizie poddano historyczne oraz

\footnotetext{
${ }^{1}$ Konferencja Narodów Zjednoczonych ds. Handlu i Rozwoju (UNCTAD, ang. United Nations Conference on Trade and Development) - organ pomocniczy Organizacji Narodów Zjednoczonych utworzony w 1964 roku w Genewie. Ma za zadanie wspieranie rozwoju gospodarczego (zwłaszcza państw rozwijających się), handlu międzynarodowego i światowych inwestycji. Obecnie członkami UNCTAD są 193 państwa, w tym Polska.
} 
aktualne (na stan badań) dane nt. działalności B+R największych przedsiębiorstw europejskich, ze szczególnym uwzględnieniem zróżnicowanych źródeł statystycznych (OECD, UE, IRMA, dane własne przedsiębiorstw). W trzecim etapie badań opracowano szczegółowy raport (Innobarometer). Raport ten opisuje uwarunkowania zmiany struktury przestrzennej działalności $\mathrm{B}+\mathrm{R}$ przedsiębiorstw oraz wskazuje na rosnącą rolę nowych państw UE (EŚW) w przyjmowaniu działów B+R korporacji (głównie) zachodnioeuropejskich (Cincera, Cozza, Tubke, 2010).

- Obserwacje własne autora niniejszego opracowania poparte danymi statystycznymi Eurostat (Eurostat, 2014a; Eurostat, 2014b). Autor pracy przeanalizował zmiany nakładów na działalność B+R na poziomie ponadregionalnym (NUTS 2) w latach 2007-2013 i na tej podstawie wskazuje na kierunki zmiany struktury przestrzennej działalności $\mathrm{B}+\mathrm{R}$ pomiędzy m.in. państwami „starej UE” oraz „,nowej UE”. Przykładowe wizualne odzwierciedlenie pomiaru działalności B $+\mathrm{R}$ prowadzonego przez EUROSTAT na poziomie NUTS 2 (za 2010 rok) znajduje się pod linkiem: http://epp.eurostat.ec.europa.eu/statistics_explained/index. php/File:GERD_by_NUTS2Map2_1.png.

\section{FORMY PROWADZENIA DZIAŁALNOŚCI BADAWCZO-ROZWOJOWEJ PRZEDSIĘBIORSTW}

Wyróżnić można kilka podstawowych form prowadzenia działalności B+R przez przedsiębiorstwa, w tym zwłaszcza przedsiębiorstwa międzynarodowe. Do jednej z najpopularniejszych typologii zalicza się wprowadzony przez UNCTAD (w dokumencie Transnational Corporations and the Internalization of $R \& D$ ) podział na działalność $\mathrm{B}+\mathrm{R}$ adaptacyjną, innowacyjną i monitoring technologii (Rosińska, 2006: 12-13).

Adaptacyjna (przystosowawcza) działalność B+R to przede wszystkim wsparcie głównej działalności produkcyjnej przedsiębiorstwa oraz wsparcie w procesie modyfikacji i/lub udoskonalenia importowanej technologii. Tego typu działalność B+R charakteryzuje koncentracja na pracach rozwojowych (np. prototypowaniu), badaniach/testach jakościowych oraz pracach przedwdrożeniowych nad koncepcjami produktów/technologii opracowywanymi w krajach macierzystych.

Innowacyjna działalność $\mathrm{B}+\mathrm{R}$ koncentruje się na pracach $\mathrm{B}+\mathrm{R}$ nakierowanych na bezpośrednie tworzenie oraz rozwój nowych produktów i technologii. Działalność ta obejmuje najważniejsze elementy procesu koncepcyjnego oraz wytwórczego nowych produktów i usług, a więc zarówno badania przemysłowe² (często poprzedzone badaniami stosowany$\mathrm{mi}^{3}$ ), jak i prace rozwojowe ${ }^{4}$ (przedkonkurencyjne). Szczególnie istotne zadania w ramach

2 Badania służące zdobyciu nowej wiedzy i umiejętności, dzięki którym możliwe będzie opracowanie innowacyjnych produktów, procesów lub usług albo wprowadzenie istotnych ulepszeń do istniejących produktów, procesów lub usług.

3 Prace badawcze podejmowane w celu zdobycia nowej wiedzy, zorientowane przede wszystkim na zastosowanie w praktyce.

${ }^{4}$ Prace rozwojowe - nabywanie, łączenie, kształtowanie i wykorzystywanie dostępnej aktualnie wiedzy i umiejętności z dziedziny nauki, technologii i działalności gospodarczej oraz innej wiedzy i umiejętności do planowania produkcji oraz tworzenia i projektowania nowych, zmienionych lub ulepszonych produktów, procesów i usług. 
tego rodzaju działalności koncentrują się wokół opracowania całościowej koncepcji nowego produktu (technologii) oraz jego weryfikacji w warunkach półtechnicznych oraz produkcyjnych. Jest to szczególnie istotny rodzaj działalności B+R, najbardziej oczekiwany z punktu widzenia kraju przyjmującego inwestycję w tym zakresie.

Działalność związana z monitoringiem technologii ma na celu uważne obserwowanie pojawiających się nowości i zmian technologicznych na innych rynkach zagranicznych. Jest to stosunkowo młody typ działalności $\mathrm{B}+\mathrm{R}$, w którym istotą jest stały monitoring rozwiązań rynkowych pojawiających się na poszczególnych rynkach, analiza zasobów wiedzy jednostek naukowo-badawczych, a także uczestnictwo (często razem z konkurentami rynkowymi) w inicjatywach wspierających działalność innowacyjną, jak klastry, parki technologiczne, centra innowacji, centra transferu technologii itp.

Przytoczona powyżej klasyfikacja nie jest oczywiście jedyną typologią form prowadzenia działalności $\mathrm{B}+\mathrm{R}$. Inne klasyfikacje przedstawiają w tym zakresie naukowcy brytyjscy (Birkinshaw, 2002) czy szwajcarscy (Gassmann, von Zedtwitz, 1999). Dodatkowo aspekty delokalizacji tzw. wysokowartościowych funkcji (w tym funkcji B+R) przedsiębiorstw podejmowane były w ostatnich latach w pracach autorów amerykańskich i australijskich (Contractor, Kumar, Kundu, Pedersen, 2010) oraz francuskich (Franck, Owen, 2006). Warto przy tym zwrócić również uwagę na istotny aspekt związany z modelami funkcjonowania przedsiębiorstw przemysłowych w warunkach tzw. gospodarki opartej na wiedzy (Rachwał, 2013: 191). Na potrzeby niniejszego artykułu przyjęto jednak pierwszą z opisanych typologii, jako, zdaniem autora, najlepiej odzwierciedlającą trendy i uwarunkowania zmian przestrzennych w tym zakresie.

\section{RELOKALIZACJA DZIAŁALNOŚCI PRODUKCYJNEJ ORAZ DZIAŁALNOŚCI B+R}

Relokalizacja (delokalizacja) to ,proces przenoszenia aktywności gospodarczej za granicę, odzwierciedlający zmiany $\mathrm{w}$ funkcjonowaniu przedsiębiorstw wynikające $\mathrm{z}$ ich adaptacji do coraz bardziej konkurencyjnego środowiska i funkcjonowania oraz szybszych zmian technologicznych" (Offshoring and Employment. Trends and Impacts, 2007: 15-16). Zjawisko to nie jest jednak nowe, ale jest to raczej kolejny sposób określenia fragmentacji produkcji, która oznacza podział procesu produkcji na części składowe wykonywane w różnych miejscach (lokalizacja), w tym również za granicą. (Boba, 2008: 47). Jak podkreśla K. Wach (2012: 194), delokalizację zwykle rozpatruje się w wąskim oraz w szerokim znaczeniu. Ta pierwsza odbywa się wewnątrz przedsiębiorstwa, a ta druga polega na przeniesieniu produkcji do podmiotu niepowiązanego kapitałowo.

Proces relokalizacji działalności produkcyjnej sprzyja tym samym bezpośrednio procesowi przenoszenia działalności $\mathrm{B}+\mathrm{R}$ przedsiębiorstw przemysłowych. Przemysł odgrywa w tym przypadku zasadniczą rolę jako elementarne źródło innowacyjności dla całej UE (Rachwał, Wiedermann, Kilar, 2009: 32-34). Co więcej, relokalizacja produkcji jest jednym z podstawowych wyznaczników celowości przenoszenia działalności $B+R$ pomiędzy poszczególnymi krajami. Szczególnie zauważalne jest to $\mathrm{w}$ perspektywie przedsiębiorstw 
z państw UE oraz w sytuacji kryzysu gospodarczego dotykającego bezpośrednio członków tejże organizacji.

Według M. Rosińskiej, do tradycyjnych przyczyn, dla których korporacje transnarodowe przenoszą swoją działalność za granicę, należą więc w tym aspekcie (Rosińska, 2006: 4):

- potrzeba adaptacji produktów bądź procesów produkcyjnych do warunków rynku kraju goszczącego,

- potrzeba zdobycia dostępu do nowych technologii i ich monitoringu,

- potrzeba dostępu do wykwalifikowanej i posiadającej niezbędne umiejętności siły roboczej.

Warto wskazać przy tej okazji na kwestię dyfuzji innowacji jako procesu powiązanego koncepcyjnie z realokacją działalności produkcyjnej i badawczo-rozwojowej przedsiębiorstw. Według E.M. Rogersa (1983: 11; za: Kosała, Wach, 2013: 113-129), przez pojęcie dyfuzji innowacji należy rozumieć proces komunikacji innowacji w systemie społecznym, czyli „rozpowszechnianie się innowacji od miejsca powstania ku członkom tego systemu” (Firszt, 2012: 20; za: Kosała, Wach, 2013: 113-129). Delokalizacja działalności badawczo-rozwojowej ma bezpośredni wpływ na międzynarodową dyfuzję innowacji. W tym kontekście dyfuzja innowacji to proces międzynarodowego upowszechnienia się innowacji. Pozwala ona bowiem na szybsze rozpowszechnienie się nowych rozwiązań produktowych, technologicznych, organizacyjnych oraz marketingowych na świecie. Cechami innowacji

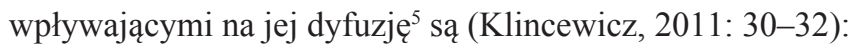

- przewaga - w stosunku do dotychczas stosowanych rozwiązań,

- zgodność - z przeszłymi doświadczeniami, wartościami i potrzebami,

- niska złożoność - łatwiej zrozumieć i użyć,

- testowalność - by samemu przekonać się o korzyściach,

- obserwowalność - pozwala obejrzeć wyniki wykorzystywania przez innych.

Realokacja działalności produkcyjnej przedsiębiorstw, jako bezpośredni wyznacznik delokalizacji działalności B+R firm, może być rozpatrywana dwuwariantowo (Wach, 2012: 192-194). Z jednej strony jako delokalizacja sensu stricto (odbywająca się wewnątrz przedsiębiorstwa), z drugiej zaś jako delokalizacja sensu largo (przeniesienie produkcji do podmiotu niepowiązanego kapitałowo i osobowo z przedsiębiorstwem macierzystym). W przypadku działalności badawczo-rozwojowej mamy do czynienia z oboma rodzajami delokalizacji, jednakże - ze względu na istotną rolę tej działalności w całości działań przedsiębiorstwa oraz konieczność pozostawiania wyników prac (opatentowanych lub nieopatentowanych) wewnątrz przedsiębiorstwa - dominuje delokalizacja typu sensu stricto.

Zdaniem S. Szukalskiego (Szukalski, 2012: 8) relokalizacja działalności badawczo-rozwojowej polega przede wszystkim na przekształceniach organizacyjnych na poziomie spółek produkcyjnych, w których działy badawczo-rozwojowe zostają w danym państwie zlikwidowane lub znacznie ograniczone, a procesy tam wykonywane zostają przeniesione do centrów

${ }^{5}$ Dyfuzja innowacji w skali międzynarodowej to proces upowszechnienia się nowego produktu wśród konsumentów na rynkach zagranicznych. Wśród czynników sprzyjających międzynarodowej dyfuzji innowacji wyróżnia się najczęściej postęp w zakresie skali i techniki rozpowszechniania informacji oraz zwiększenie - w wyniku zmian technologicznych i społecznych - mobilności dóbr, kapitału, ludzi i idei. 
badawczo-rozwojowych w innych krajach. Zmiany organizacyjne oznaczają przekształcenia struktur organizacyjnych na poziomie firm produkcyjnych, w których w konsekwencji pewne działy zostaną zlikwidowane, a procesy tam wykonywane zostaną przeniesione. Utworzenie centrum $\mathrm{B}+\mathrm{R}$, nadanie mu określonych funkcji oraz różnicowanie statusu komórek i jednostek organizacyjnych to kolejna zmiana typu organizacyjnego. Przygotowanie i przeprowadzenie zmian trwa średnio dwa lata (Szukalski, 2012: 48-52).

Kierunki realokacji działalności badawczo-rozwojowej są zróżnicowane i uwarunkowane czynnikami opisanymi w dalszej części pracy. Wskazać jednak należy, iż realokując działalność badawczo-rozwojową w innym kraju, dane przedsiębiorstwo powinno: zdefiniować wizję prowadzenia działalności badawczej i określić jej cele strategiczne, opracować model operacyjny i plan implementacji projektu procesów biznesowych (struktura organizacyjna, plan zatrudnienia, szkolenia), przeprowadzić właściwą migrację procesów (Szukalski, 2012: 54).

\section{UWARUNKOWANIA ZMIANY STRUKTURY PRZESTRZENNEJ DZIAŁALNOŚCI B+R EUROPEJSKICH PRZEDSIĘBIORSTW PRODUKCYJNYCH}

Uwarunkowania zmian podzielić należy na wewnętrzne - czyli takie, które leżą wewnątrz przedsiębiorstwa, i zewnętrzne, czyli takie, które nie zależą od przedsiębiorstwa, ale znajdują się w jego otoczeniu (Wach, 2008: 29-36; Kosała, Wach, 2013: 113-129). Do podstawowych uwarunkowań zewnętrznych zmiany struktury przestrzennej działalności B+R europejskich przedsiębiorstw produkcyjnych w warunkach kryzysu gospodarczego należą: uwarunkowania ekonomiczne, technologiczne, społeczne (w tym demograficzne i kulturowe), administracyjno-prawne (w tym instytucjonalne) - zgodnie z klasyfikacją ogólnego otoczenia przedsiębiorstw (PEST czy rozwinięcia SLEP, PESTEL ${ }^{6}$ ) przyjętą w naukach ekonomicznych, zwłaszcza w zarządzaniu strategicznym (Wach, 2008: 29-36), w tym zwłaszcza z odpowiednio wyartykułowanymi elementami charakterystycznymi dla działalności badawczo-rozwojowej.

\section{Uwarunkowania prawne (w tym administracyjno-instytucjonalne)}

Dodatkowo do istotnych uwarunkowań administracyjno-prawnych zaliczyć należy przepisy prawne, regulacje i unormowania związane z prowadzeniem działalności badawczo-rozwojowej w poszczególnych krajach. Przepisy te mają bezpośredni wpływ na własność przemysłową, ulgi podatkowe, odpisy amortyzacyjne infrastruktury $B+R$ i inne. Są więc one szczególnie istotne $\mathrm{w}$ procesie funkcjonowania komórek $\mathrm{B}+\mathrm{R} \mathrm{w}$ przedsiębiorstwach (Burnat-Mikosz, 2013: 68).

\section{Uwarunkowania ekonomiczne (w tym finansowe)}

Do głównych uwarunkowań ekonomicznych mających wpływ na zmianę struktury przestrzennej działalności $\mathrm{B}+\mathrm{R}$ europejskich przedsiębiorstw produkcyjnych należą: koszty

${ }^{6}$ Analiza PEST obejmuje cztery grupy uwarunkowań, a jej rozszerzoną wersją jest analiza PESTEL, obejmująca czynniki polityczne, ekonomiczne, społeczno-kulturowe, technologiczne, ekologiczne, prawne. 
prowadzenia działalności gospodarczej w danym państwie (szczególnie z zakresie B+R) oraz zdolność danego państwa do (współ)finansowania działalności B+R.

W pierwszym aspekcie działalność $\mathrm{B}+\mathrm{R}$ jest działalnością generującą szczególnie wysoki poziom kosztów. Związane jest to m.in. z koniecznością zakupów istotnego kosztowo sprzętu laboratoryjnego, sprzętu do prototypowania (często pełnowymiarowe linie produkcyjne), know-how oraz usług doradczych od jednostek naukowych itp. Niezbędnymi nakładami w ramach realizacji projektów $\mathrm{B}+\mathrm{R}$ są również nakłady na koszty osobowe, koszty operacyjne (np. surowce do prototypowania, odczynniki analityczne itp.) oraz ogólne (delegacje, udziały w konferencjach naukowych, koszty patentowe itp.).

Równie istotne co kwestie kosztowe są kwestie przychodowe, szczególnie związane z możliwościami uzyskania ulg lub dotacji na działalność badawczo-rozwojową. Coroczne raporty firmy doradczej Deloitte (Przegląd zachęt na działalność $B+R$ na świecie) wskazują kraje o największym potencjale przyciągania inwestycji do sektora badań i rozwoju. W raporcie tym wskazano, iż państwa, które oferują zachęty na prowadzenie działalności $\mathrm{B}+\mathrm{R}$, postrzegane są jako atrakcyjne lokalizacje do tworzenia i rozbudowy ośrodków badawczo-rozwojowych, a także rozprzestrzeniania działalności badawczej na inne kraje. Tego typu działania mogą skutecznie przyczynić się do dynamicznego rozwoju globalnej działalności B+R oraz powstania cennych praw własności intelektualnej (Burnat-Mikosz, 2013: 92). Przykładowe rodzaje zachęt w tym zakresie to: zwolnienia podatkowe, możliwości umorzeń kredytów, preferencyjne oprocentowanie kredytów, poręczenia instytucji państwowych itp.

\section{Uwarunkowania społeczne (w tym demograficzne i kulturowe)}

Czynnik ludzki stanowi istotną barierę w rozwijaniu innowacyjności firm. Brak potencjalnych pracowników o odpowiednich kwalifikacjach wskazało, jako bardzo dużą lub dużą barierę rozwoju innowacyjności, 59\% ankietowanych firm w grupie polskich i zagranicznych przedsiębiorców ulokowanych na terenie regionu łódzkiego i wielkopolskiego (Mazurek, 2008: 11).

Dodatkowo istnieje wyraźna potrzeba wysokiego stopnia elastyczności w obszarze $\mathrm{B}+\mathrm{R}$, polegająca na możliwości natychmiastowego dostępu do grona pracowników o odpowiednich kwalifikacjach, z uwagi na szybko zmieniające się technologie. W efekcie rynki, które mogą zapewnić bazę odpowiednich pracowników, będą przyciągać korporacje do lokowania działalności B+R na swych terytoriach (Rosińska, 2006: 14).

Istotne jest również, iż zmiany demograficzne charakteryzujące się starzeniem się społeczeństw w wielu krajach rozwiniętych mogą spowodować niedostatek pracowników o odpowiednich kwalifikacjach, a tym samym także zachęcić korporacje do lokowania swoich filii tam, gdzie pracownicy o niezbędnych kwalifikacjach istnieją w dostatecznych ilościach (Rosińska, 2006: 17).

Dodatkowo wielu autorów (Niebuhr, 2006; Contractor, Kumar, Kundu, Pedersen, 2010) wskazuje na bezpośredni wpływ czynników kulturowych na stymulowanie działalności innowacyjnej (w tym związanej ze sferą B+R) w przedsiębiorstwach przemysłowych. Tło kulturowe ma bezpośredni wpływ na talenty i umiejętności pracowników, m.in. na kreatywność 
pracowników działów B+R. Heterogeniczność kulturowa społeczeństw przekłada się bowiem na zdolność osób do kreowania nowych pomysłów, idei itp. Tym samym przykład Niemiec wskazuje, że kraje korzystające z pracowników pochodzących z emigracji (na stanowiskach inżynieryjnych) cechują się wyższym poziomem innowacyjności (Niebuhr, 2006: 67-71).

\section{Uwarunkowania technologiczne (w tym naukowe)}

Do uwarunkowań technologicznych oraz naukowych zmiany struktury przestrzennej działalności B+R w dobie kryzysu gospodarczego zaliczyć należy możliwość współpracy nowo lokowanej firmy w ramach zgrupowań klastrowych, centrów transferu technologii, centrów innowacji w kraju przyjmującym inwestycję. Szczególne znaczenie ma w tym przypadku również bliskość cenionych jednostek naukowych. Analizy sporządzone na potrzeby Polskiej Agencji Rozwoju Przedsiębiorczości (Santarek, 2008: 7-18) wskazują na wyraźny rozwój modelu innowacji otwartej (open innovation), polegającego m.in. na zlecaniu części prac $\mathrm{B}+\mathrm{R}$ do uczelni i instytutów naukowych.

Badania przeprowadzone $\mathrm{w}$ grupie polskich i zagranicznych przedsiębiorców ulokowanych na terenie regionu łódzkiego (Mazurek, 2008: 14-19) oraz wielkopolskiego wskazują, iż najważniejszymi barierami ograniczającymi współpracę na linii przedsiębiorca - jednostka naukowa są: niedostosowanie oferty jednostek naukowych do oczekiwań biznesowych przedsiębiorców (wskazane przez 37\% badanych), niska jakość oferowanych usług oraz wysokie koszty badań. Czynniki te mają bezpośrednie odzwierciedlenie w otoczeniu administracyjno-prawnym związanym z działalnością $\mathrm{B}+\mathrm{R}$, w tym w szczególności w aspektach rozliczania usług $\mathrm{B}+\mathrm{R}$ pomiędzy uczelniami oraz naukowcami a przedsiębiorstwami.

Wskazane powyżej w sposób syntetyczny cztery grupy uwarunkowań (na podstawie analizy PEST) przekładają się bezpośrednio na kierunki przestrzenne zmiany struktury działalności $\mathrm{B}+\mathrm{R}$ opisane $\mathrm{w}$ dalszej części opracowania.

\section{GŁÓWNE KIERUNKI PRZESTRZENNE ZMIANY STRUKTURY DZIAŁALNOŚCI B+R EUROPEJSKICH PRZEDSIĘBIORSTW PRODUKCYJNYCH}

Analizując zachowania europejskich przedsiębiorstw, można wskazać na pięć głównych kierunków zmiany struktury przestrzennej działalności badawczo-rozwojowej. Wnioski takie oparto na analizach dokumentów źródłowych i własnych obserwacjach opisanych w pierwszej części pracy. Szczególnie interesujące wydaje się być w tym przypadku wykorzystanie wyników badań opracowanych na zlecenie Dyrekcji Generalnej Komisji Europejskiej. Wskazują one m.in. na główne przyczyny delokalizacji działalności $B+R$, mające podstawowe znaczenie dla wskazania kierunków delokalizacji. Do przyczyn tych zaliczają się: wypełnienie rynku wewnętrznego, rosnąca konkurencja na rynku UE, regulacje administracyjno-prawne itp. Do wyznaczników nowych lokalizacji zaliczyć zaś należy m.in.: dostęp do wykwalifikowanej kadry pracowniczej, dostęp do jednostek naukowych, obecność konkurencji, dogodne 
uwarunkowania prawne, stabilność makroekonomiczną państwa, jak również dostęp do pomocy publicznej w zakresie B+R (Cincera, Cozza, Tubke, 2010: 10-13).

Na podstawie obserwacji i analizy przyczynowo-skutkowej oraz przytaczanych badań empirycznych zasygnalizować można pięć podstawowych kierunków delokalizacji (tab. 1):

- kraje UE 27 - kraje BRIC,

- kraje UE 15 - kraje ESW,

- kraje UE 27 - kraje NAFTA,

- kraje ESW - kraje ESW,

- kraje UE 15 - kraje UE 15.

\section{Kierunek I: kraje UE $27^{7}-$ kraje BRIC $^{8}$}

Kierunek do krajów BRIC wyznacza obecny trend w zmianie lokalizacji działalności $\mathrm{B}+\mathrm{R}$ europejskich przedsiębiorstw przemysłowych. Aspekty kosztowe i prawno-administracyjne oraz demograficzne są w tym przypadku aspektami dominującymi w uzasadnianiu tej zmiany. Bardzo często zauważalny jest $w$ tym przypadku efekt łańcuchowy - np. lokalizacja centrów B+R poddostawców i kooperantów dużych firm produkcyjnych w bezpośredniej bliskości ich zakładów lub centrów badawczych (Eurostat, 2014a).

\section{Kierunek II: kraje UE $15^{9}$ - kraje ESW ${ }^{10}$}

Kierunek do krajów Europy Środkowej i Wschodniej jest popularny, ale wypierany od 2007 roku przez kierunek I ze względu na wzrost kosztów prowadzenia działalności w tych państwach oraz (często) niekorzystne aspekty prawno-administracyjne. Zauważalne jest wyspecjalizowanie regionu ESW w przyjmowaniu inwestycji z branż automotive (samochodowej), avio (lotniczej), IT, co jest związane m.in. z dobrą znajomością języka niemieckiego w Rumunii, na Węgrzech i w Czechach (Eurostat, 2014c).

\section{Kierunek III: kraje UE 27 - kraje NAFTA}

Kierunek do krajów NAFTA nabiera obecnie znaczenia ze względu na tzw. rewolucję łupkową w USA i Kanadzie oraz preferencje celne Meksyku. Ważna w tym przypadku jest rola monitoringowej działalności B+R. Kierunek ten jest szczególnie zauważalny w przedsiębiorstwach z branży samochodowej (Eurostat, 2014c).

${ }^{7}$ Wielka Brytania, Irlandia, Szwecja, Finlandia, Hiszpania, Portugalia, Niemcy, Francja, Grecja, Włochy, Czechy, Słowacja, Węgry, Słowenia, Polska, Rumunia, Bułgaria, Malta, Cypr, Litwa, Łotwa, Estonia, Belgia, Holandia, Luksemburg, Austria, Dania.

${ }^{8}$ Brazylia, Rosja, Indie, Chiny.

9 Wielka Brytania, Irlandia, Szwecja, Finlandia, Hiszpania, Portugalia, Niemcy, Francja, Grecja, Włochy, Belgia, Holandia, Luksemburg, Austria, Dania.

${ }^{10}$ Polska, Czechy, Słowacja, Węgry, Ukraina, Białoruś, Litwa, Łotwa, Estonia. 


\section{Kierunek IV: kraje ESW - kraje ESW}

Kierunek ten jest niszowy z tendencją rosnącą. W decyzjach o zmianie lokalizacji najważniejszy wpływ mają uwarunkowania ekonomiczne, technologiczne i kulturowe. Silna jest pozycja Polski (Inter Groclin - Ukraina, Ciech, Maspex - Rumunia (Eurostat, 2014c).

\section{Kierunek V: kraje UE 15 - kraje UE 15}

Kierunek ten jest niszowy, z tendencją opadającą. Incydentalne przypadki zmian spowodowane są czynnikami technologicznymi i (rzadziej) ekonomicznymi (Eurostat, 2014c).

Tab. 1. Syntetyczne zestawienie kierunków zmiany struktury przestrzennej działalności B+R europejskich przedsiębiorstw przemysłowych

\begin{tabular}{|c|c|c|c|c|}
\hline $\begin{array}{c}\text { Kierunek } \\
\text { zmiany struktury } \\
\text { przestrzennej } \\
\text { działalności } \\
\text { badawczo- } \\
\text {-rozwojowej }\end{array}$ & $\begin{array}{c}\text { Dominujący } \\
\text { model } \\
\text { prowadzenia } \\
\text { działalności } \\
\mathrm{B}+\mathrm{R} \text { w nowej } \\
\text { lokalizacji }\end{array}$ & $\begin{array}{l}\text { Dominujące } \\
\text { uwarunkowania } \\
\text { delokalizacji }\end{array}$ & $\begin{array}{c}\text { Przykłady } \\
\text { przedsiębiorstw }\end{array}$ & Uwagi \\
\hline $\begin{array}{l}\text { Kierunek I: } \\
\text { kraje UE - kraje } \\
\text { BRIC }\end{array}$ & $\begin{array}{l}\text { adaptacyjny / } \\
\text { innowacyjny }\end{array}$ & $\begin{array}{l}\text { ekonomiczne, } \\
\text { demograficzne, } \\
\text { kulturowe }\end{array}$ & $\begin{array}{l}\text { Novartis, } \\
\text { Astra Zeneca, } \\
\text { GlaxoSmithKline }\end{array}$ & $\begin{array}{l}\text { dominacja sektorowa: } \\
\text { Chiny - przemysł } \\
\text { ciężki i chemiczny, } \\
\text { IT, Indie - IT, } \\
\text { farmacja, Brazylia - } \\
\text { przemysł spożywczy, } \\
\text { Rosja - przemysł } \\
\text { przetwórczy }\end{array}$ \\
\hline $\begin{array}{l}\text { Kierunek II: } \\
\text { kraje UE } 15 \text { - } \\
\text { kraje ESW }\end{array}$ & adaptacyjny & $\begin{array}{l}\text { ekonomiczne, } \\
\text { demograficzne, } \\
\text { administracyjno- } \\
\text {-prawne }\end{array}$ & $\begin{array}{l}\text { VW, } \\
\text { Volvo }\end{array}$ & $\begin{array}{l}\text { zatrzymanie } \\
\text { rosnącego trendu na } \\
\text { rzecz krajów BRIC } \\
\text { i NAFTA }\end{array}$ \\
\hline $\begin{array}{l}\text { Kierunek III: } \\
\text { kraje UE - kraje } \\
\text { NAFTA }\end{array}$ & $\begin{array}{l}\text { adaptacyjny } \\
\text { / monitoring }\end{array}$ & $\begin{array}{l}\text { ekonomiczne, } \\
\text { demograficzne }\end{array}$ & $\begin{array}{l}\text { BMW, } \\
\text { Audi }\end{array}$ & $\begin{array}{l}\text { warunkowany } \\
\text { rewolucją łupkową }\end{array}$ \\
\hline $\begin{array}{l}\text { Kierunek IV: } \\
\text { kraje ESW - } \\
\text { kraje ESW }\end{array}$ & adaptacyjny & $\begin{array}{l}\text { ekonomiczne, } \\
\text { technologiczne }\end{array}$ & $\begin{array}{l}\text { Inter Groclin- } \\
\text {-Leoni, } \\
\text { Ciech, } \\
\text { Maspex }\end{array}$ & $\begin{array}{l}\text { kierunek niszowy } \\
\text { - tendencja } \\
\text { zdominowana przez } \\
\text { firmy z Polski }\end{array}$ \\
\hline $\begin{array}{l}\text { Kierunek V: } \\
\text { kraje UE } 15 \text { - } \\
\text { kraje UE } 15\end{array}$ & monitoring & $\begin{array}{l}\text { technologiczne, } \\
\text { ekonomiczne }\end{array}$ & Alstom & $\begin{array}{l}\text { kierunek niszowy - } \\
\text { przemysł high-tech }\end{array}$ \\
\hline
\end{tabular}

Źródło: opracowanie własne na podstawie danych Eurostat

Konsekwencją opisanych powyżej zmian jest przeniesienie punktu ciężkości prowadzonych działań badawczo-rozwojowych poza terytorium „starej” UE (UE 15) na terytoria pozaeuropejskie lub (rzadziej) „,nowej” UE. Może to mieć negatywny wpływ na realizację 
przez UE tzw. Strategii Lizbońskiej, która ma doprowadzić do wzrostu konkurencyjności UE na tle rynku światowego (Eurostat, 2014d).

\section{Podsumowanie}

Postępujące procesy globalizacji i internalizacji zachodzące w światowej gospodarce powodują, iż korporacje europejskie, mając świadomość konieczności skutecznego konkurowania z firmami (zwłaszcza) z USA i Azji, muszą podejmować działania z jednej strony zwiększające ich innowacyjność, takie jak otwieranie nowych jednostek badawczo-rozwojowych, z drugiej zaś - związane z ograniczaniem kosztów i optymalizowaniem procesów badawczych w aspektach, m.in. HR, technologicznych i prawnych. Wynikową takiej sytuacji jest postępująca zmiana struktury przestrzennej działalności badawczo-rozwojowej europejskich przedsiębiorstw przemysłowych, zauważalna na przestrzeni ostatnich kilku lat. Proces ten postępuje w sposób ciągły, ale i częściowo nieprzewidywalny (np. powodowany rewolucją łupkową w USA), jednakże podstawowe uwarunkowania, trendy i konsekwencje można wskazać bardzo wyraźnie jako charakterystyczne dla tego zagadnienia.

\section{Literatura \\ References}

Birkinshaw, J. (2002). Managing Internal. R\&D Networks in Global Firms. What Sort of Knowledge is Involved? Long Range Planning, 35, 245-267.

Boba, K. (2008). Delokalizacja produkcji między Niemcami a Polską. Integracja gospodarcza w rozszerzonej UE: od wolnego handlu do unii walutowej, 1, 402-405.

Borowiec, A. (2010). Dyfuzja innowacji w sieciach przedsiębiorstw, procesy, struktury, formalizacja, uwarunkowania poprawiajace zdolność do wprowadzania innowacji. Foresight sieci gospodarczej Wielkopolski. Poznań: Wydawnictwo Politechniki Poznańskiej.

Burnat-Mikosz, M. (2013). Przegląd zachęt na działalność $B+R$ na świecie w 2013 r. Warszawa: Wydawnictwo Deloitte.

Cincera, M., Cozza, C., Tubke, A. (2010). Drivers and policies for increasing and internationalising $\mathrm{R} \& \mathrm{D}$ activities of EU MNEs. IPTS working paper on corporate $R \& D$ and innovation, 2.

Contractor, F., Kumar, V., Kundu, S., Pedersen, T. (2010). Reconceptualizing the Firm in a World of Outsourcing and Offshoring: The Organizational and Geographical Relocation of High-Value Company Functions. Journal of Management Studies, 47: 8.

Delocalization of $R \& D$ - Development to follow the production trend? (2006). Badania przeprowadzone przez firmę konsultingową Arthur D. Little.

Eurostat (2014a, 9 stycznia). Pozyskano z http://epp.eurostat.ec.europa.eu/statistics_explained/index. php?title=File:Gross_domestic_expenditure_on_R\%26D_by_source_of_funds,_2005_and_2010_ (\%25_of_total_gross_expenditure_on_R\%26D).png\&filetimestamp $=20121016060847$

Eurostat $(201 \overline{4}$ b, 9 stycznia). Pozyskano z http://epp.eurostat.ec.europa.eu/statistics_explained/index. php/Europe_2020_indicators_-_research_and_development)

Eurostat (2014c, 9 stycznia). Pozyskano z http://epp.eurostat.ec.europa.eu/cache/ITY_SDDS/en/rd_esms.htm Eurostat (2014d, 9 stycznia). Pozyskano z http://eur-lex.europa.eu/pl/dossier/dossier_13.htm

Franck, B., Owen, R. (2006). Fundamental R\&D Spillovers and the Internationalization of a Firm's Research Activities. Pozyskano z htpp://www.etsg.org/ETSG2005/papers/owen.pdf 
Gassmann, J., Zedtwitz, M. von (1999). New concepts and trends in international R\&D organization. Research Policy, 28, 231-250.

Jurgens, U., Krzywdzinski, M. (2009). Changing East-West Division of Labour in the European Automotive Industry. European Urban and Regional Studies, 16 (1),16-27.

Klincewicz, K. (2011). Dyfuzja innowacji. Jak odnieść sukces w komercjalizacji nowych produktów i ustug. Warszawa: Wydawnictwo Wydziału Zarządzania Uniwersytetu Warszawskiego.

Kosała, M., Wach, K. (2013). Czynniki determinujące dyfuzję innowacji na poziomie makro, mezo i mikro. W: K. Zieliński (red.). Czynniki makroekonomiczne i sektorowe wptywajace na rozwój przedsiębiorczości. Katowice: Wydawnictwo Naukowe Śląsk, 113-129.

Mazurek, B. (2008). Model transferu wiedzy i technologii. Łódź: Wydawnictwo Społecznej Wyższej Szkoły Przedsiębiorczości i Zarządzania w Łodzi.

Niebuhr, A. (2006). Migration and innovation: Does cultural diversity matter for regional R\&D activity? HWWI Research Paper, 3, 2-26.

Odrobina, A. (2012), Delokalizacja jako skutek globalizacji i integracji, W: Gospodarka światowa $w$ warunkach globalizacji i regionalizacji rynków, S. Kilaszewski, E. Molendowski (red.).Warszawa: Difin.

Offshoring and Employment. Trends and Impacts (2007). OECD. Danvers.

Rachwał, T. (2013). Rola przedsiębiorstw przemysłowych w rozwoju gospodarki opartej na wiedzy. Prace Komisji Geografii Przemystu Polskiego Towarzystwa Geograficznego, 21, 189-211.

Rachwał, T., Wiedermann, K., Kilar, W. (2009). Rola przemysłu w gospodarce układów regionalnych Unii Europejskiej. Prace Komisji Geografii Przemystu Polskiego Towarzystwa Geograficznego, $14,31-42$.

Rosińska, M. (2006). Działalność badawczo-rozwojowa korporacji transnarodowych jako podstawa tworzenia globalnej sieci B+R. W: K. Kaszuba, St. Wydymus (red.). Handel międzynarodowy a rozwój gospodarczy. Rzeszów: Wydawnictwo Wyższej Szkoły Zarządzania w Rzeszowie, 265-279.

Santarek, K. (red.) (2008). Transfer technologii z uczelni do biznesu. Tworzenie mechanizmów transferu technologii. Warszawa: Wydawnictwo PARP.

Szukalski, S. (2012). Procesowe i organizacyjne innowacje w centrach usług wspólnych. Acta Universitatis Lodziensis. Folia Oeconomica, 268, 107-123.

Wach, K. (2008). Regionalne otoczenie małych i średnich przedsiębiorstw. Kraków: Wydawnictwo Uniwersytetu Ekonomicznego w Krakowie.

Wach, K. (2012). Europeizacja małych i średnich przedsiębiorstw: rozwój przez umiędzynarodowienia. Warszawa: Wydawnictwo Naukowe PWN.

Michal Becla, mgr, doktorant na Uniwersytecie Ekonomicznym w Krakowie. Zainteresowania badawcze i zawodowe autora koncentrują się wokół zagadnień pomocy publicznej, transferu technologii oraz modeli funkcjonowania centrów badawczo-rozwojowych w przedsiębiorstwach przemysłowych, szczególnie z zakresu branż wysokich i średniowysokich technologii. Szczególne znaczenie ma w tym przypadku analiza praktycznych rozwiązań stosowanych w opisywanych aspektach w przedsiębiorstwach liderach w swoich segmentach rynkowych.

Michal Becla, Ph.D. student at the Cracow University of Economics Academic and professional areas of interest of the author are connected with notions of public aid; transfer of technology; and models of functioning of R\&D centers in industrial enterprises, with special attention paid to sectors of high and medium-high technology. In this case, analysis of practical solutions implemented by enterprises has particular meaning. .

\section{Adres/address:}

Uniwersytet Ekonomiczny w Krakowie

ul. Rakowicka 27, 31-510 Kraków, Polska

e-mail: michal.becla@wp.pl 